\title{
Innovation and knowledge transference in a cluster user-driven innovation perspective - the Inovcluster experience
}

\author{
Teresa Paiva ${ }^{a^{*}}$, Cláudia Domingues ${ }^{\mathrm{b}}$, and Luís Pinto de Andrade ${ }^{\mathrm{c}}$ \\ ${ }^{a}$ Unidade de Investigação para o Desenvolvimento do Interior, Instituto Politécnico da Guarda, Av. Dr. \\ Francisco Sá Carneiro, 50, 6300-559 Guarda, Portugal \\ ${ }^{\mathrm{b}}$ Inovcluster, Portugal \\ ${ }^{\mathrm{b}}$ Instituto Politécnico de Castelo Branco, Portugal \\ ${ }^{*}$ Corresponding author \\ tpaiva@ipg.pt \\ TEL: +351-962353794
}

Received: 22 April 2015; Published online: 18 April 2016

\begin{abstract}
Our purpose with this article is to show the importance of assessing trends and promoting innovation in a real business context, through a cluster ecosystem, mainly composed of micro-enterprises in the agro-industrial Portuguese sector.

As many studies show, Inovcluster (which has 158 associates, from which 120 are enterprises) is also a geographic region cluster, which improves innovation performance of businesses seeking to gain competitiveness and ability to improve their exportations in the agro-industrial Portuguese sector.

The role of the cluster is fundamental to creating a model for knowledge transfer of innovation capacity, interconnecting its institutional, scientific and business associates. This model has to be adapted to the sector and enterprise characteristics, relying in an interconnecting structure which is more or less decentralized according to the mentioned features. Here we present an experience and case study of the Inovcluster ecosystem and its trends and innovation transfer to business value creation, contextualized within the regional strategy for smart specialization.

We have shown how, through the establishment of an Inovcluster network, it is possible to integrate the contribution of different research and academic centres, channelled to assist micro-enterprises by innovating within a geographical constraint.
\end{abstract}

Keywords: User driven innovation; Value creation; Trends; Smart specialization strategy; Cluster

\section{Introduction}

Inovcluster, created in May 2009, is a cluster association based in a strategic cooperation between entities seeking a series of values, principles and methodologies that complement each other. The quality and variety of the projects and the services provided, focusing on partners and the pursuit of innovation, are among its main goals.

The Cluster is formed of a set of 158 members, within different economic areas, in which their business associates cover the economic sectors of meat, fish, honey, milk and dairy products, olive oil, fruit and vegetables, wine, vine and cereals. About $30 \%$ of Inovcluster members are located outside the territorial scope recognized for the Agro-industrial Centre Cluster membership. Thus, the central region of Portugal is, as a whole, the area where the cluster activity is developed.

The main concern of Inovcluster is to offer 
services and knowledge to its business associates so that they may improve their competitiveness, innovation and sustainability. Therefore, the Cluster designed its strategy towards this aim. It sought to integrate the different activity areas so that it was possible to enhance and achieve its main goal, as shown in figure 1 .

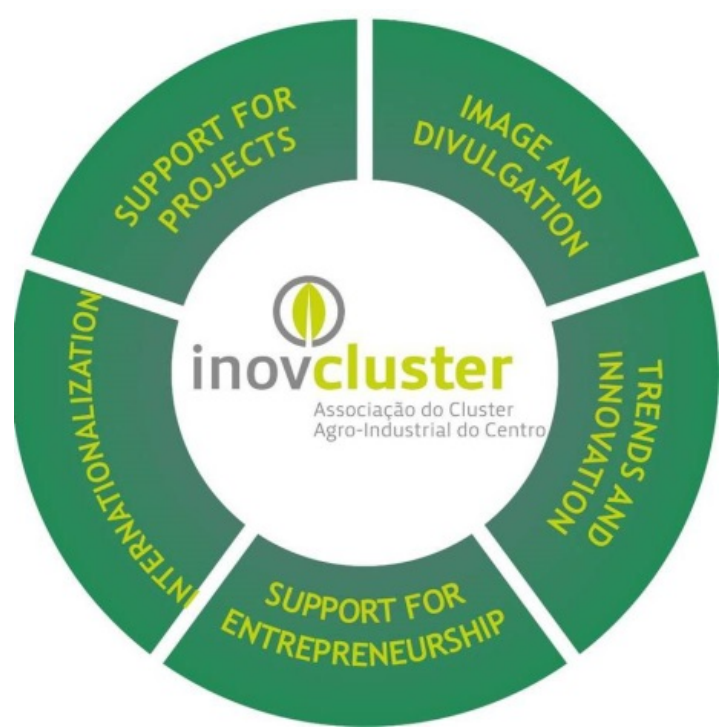

Figure 1: Inovcluster intervention areas - Source: Inovcluster

This preoccupation led Inovcluster to develop its own model of knowledge transfer, grounded in the main theoretical scientific concepts in the study field of innovation, trends and smart specialization (Foray et al., 2012). Therefore, the cluster seeks to boost the relationships between its associates and promote strategic development to help them launch new products or innovate in services, thereby reaching new markets and developing new processes.

\section{Theoretical Framing}

Rosted (2005) says that there are three sources of innovation, depending on the competitive landscape of the company: price competition; new research and technology; and non-recognised consumer needs (Chang \& Chen, 2004). Some companies draw inspiration from all three sources and most of them need to develop skills. Businesses specializing in only one type of innovation are rare.

As we may observe, the social and economic context alters if there is a more empowered public. All changes produced in the market have to follow this trend (Bar \& Riis, 2000). Consequently, besides the technical and scientific breakthroughs, we have to notice what people want, how and when. This means that consumer centred innovation is fundamental for businesses to be updated and to follow society development (Bar \& Riis, 2000).

User-driven innovation implies that businesses constantly strive to deliver a product to provide consumers with a special value offer or experience, which is completely different from the competition. This perspective forces businesses to a profound understanding of customer needs as well as the ability to translate it into products, services or experiences that are unique (Rosted, 2005; Holmquist, 2004; Bar \& Riis, 2000). It is characterized by the systematic scientific mapping of consumer needs and the company's capacity to transform it into goods.

This concept was firstly tied to innovations carried out by consumers in order to increase the utility value of the product (Hippel, Thomke and Sonncak, 1999 cited in Rosted (2005)), but it wasn't long before commercial oriented innovation was also considered as user driven innovation. Even if the consumer is not an active part of the process, the company may map consumer needs in a scientific and systematic way and apply non-recognised user needs as an innovation source. The methodology and technology necessary to develop these scientific studies are sophisticated and not available to every business company. Even trend watching or cool hunting (Gomes \& Francisco, 2013; Pedroni, 2011) are important techniques, not as scientific or as rigorous as a methodology should be, but with a strong insight nevertheless, when they try to identify the different consumer trends that are being designed, how consumers think, and what they need and want (COIN - Collaborative Innovation Networks, 2009). Furthermore, the process of user-driven innovation doesn't stop here. It has to follow sequentially different 
steps which themselves involve technology and scientific and technical knowledge, as shown in figure 2 .

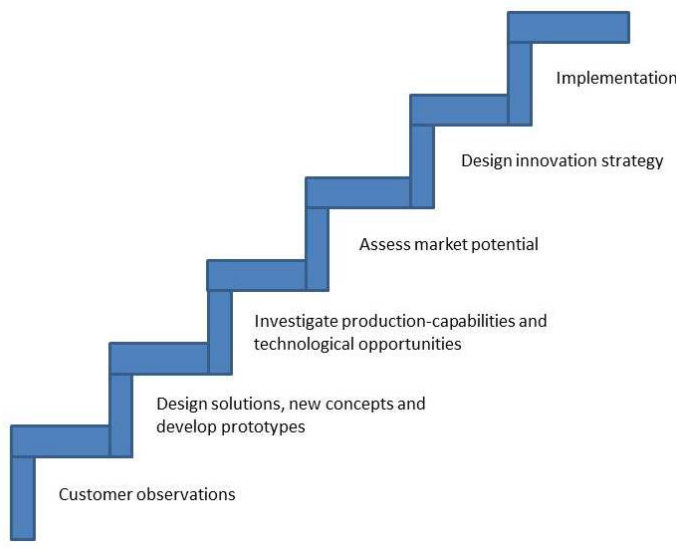

Figure 2: The user-driven innovation process Source: Adapted from Rosted (2005)

However, new products are not the only source of innovation and market competition strengthening. In Europe, it is a fact that manufacturing success also depends on the ability of the company to create and supply innovative services, design, marketing and logistics, as well as the product, in spite of the fact that regional and industrial policies and tools still not take sufficient account of these market variables. This service innovation ${ }^{1}$ and its transformative power contributes to the transformation of the traditional and emerging industries, as the change it may imply can be disruptive and consequently empowering to the company's market activity, increasing its competitive positioning (UNIDO, 2011). For Europe as a whole and for the individual regions, it is important to increase the service innovation potential and support the transformation of innovation into a product or experience with added value for the market (ILO, 2009; GTZ, 2007). In this way, Europe

\footnotetext{
${ }^{1}$ Service innovation comprises new or significantly improved service concepts and offerings as such service infrastructure, customer processing, business models, commercialisation, service productivity and hybrid forms of innovation serving several user groups in different ways simultaneously (Clusters and Support for SMEs Unit, 2012).
}

believes that it will foster structural change and economic growth, and in this spirit a Cohesion Policy for 2014-2020 was created, where the European regions are going to be asked to draw a national and regional innovation strategy for smart specialisation ${ }^{2}$ (Doranova, Griniece, Miedzinsky, \& Reid, 2012; Smart Specialization Platform, 2011; Committee of the Regions of the European Union, 2012; Organisation for Economic Cooperation and Development, 2013), which will permit regions to reinforce their advantages and channel financial and other different support to a specific group of an economic sector.

Due to the above, and knowing that one of the key economic activities that are going to be fundamental for Portugal and its Central Region is the bio-economy and the food agro-industrial sector, it was important for Inovcluster to boost the innovation process of its business associates, cementing its strategy in user-driven innovation, so that the market impact is stronger. Consequently, the objective of Invocluster is to improve the competitiveness of the country/region/agro-industrial sector, gathering the adequate competences to help business companies overcome their lack of ability in the research for innovation and service innovation, helping them to develop new strategies and new products.

\section{Model}

Currently, Inovcluster has 158 associates and $75 \%$ of them are business enterprises. Around $10 \%$ are research and technology development centres/high education institutions, $4 \%$ are municipalities and $14 \%$ cooperatives and sector associations. In order to achieve these numbers, the cluster pursues the implementation of a set of initiatives that stimulate the agglomeration economy. The objective is to encourage cooperation and networking, therefore achieving more qualification and modernization of businesses,

\footnotetext{
${ }^{2}$ Smart specialization is an improved Cohesion policy of the European Union that focus on the policy and investments support of national / regional priorities, challenges and needs for knowledge based development, build on each country/region's strengths, competitive advantages and potential for excellence (Clusters and Support for SMEs Unit, 2012).
} 
in addition to increasing applied and scientific knowledge of other partners. Therefore, Inovcluster is a facilitator in the interrelationships with its partners as well as in further relationships with other entities. With this goal in mind, the Cluster design is the interrelationship model of knowledge transfer as shown in figure 3 .

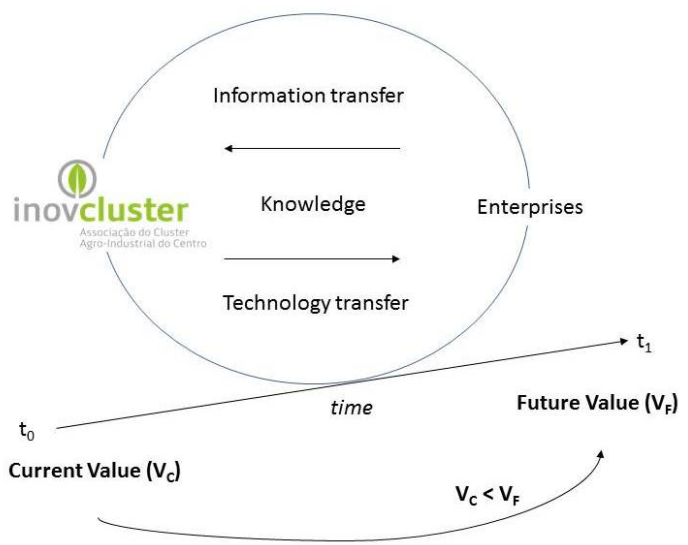

Figure 3: Induced mechanism for creating added value cycles - Source: Inovcluster - adapted from Santos et al. (2011)

This model reflects the special relevance in increasing the competitiveness of the clusters by getting together science, industry and other stakeholders, to explore new and emerging opportunities geared towards social, environmental and economic new challenges and promoting new businesses, consolidating the existing ones and improving employment in the agro-industrial sector. This model also permits a stronger impact of Inovcluster in the Centre region, particularly through new products, markets, processes and innovative service strategies, as its high quality and strong technological innovations may undergo several cycles of Research, Development and Innovation (RD\&I) to submit new projects.

Thus, the great strategic goal of Inovcluster is to enhance innovation, wealth creation, employment and well-being in the agro-industrial system, in order to connect information, knowledge and technology (flow created and transferred), which are essential tools for the development and strengthening of this system value, in a logic of economic network and agglomeration, in the context of a smart specialization region, as shown in figure 4 .
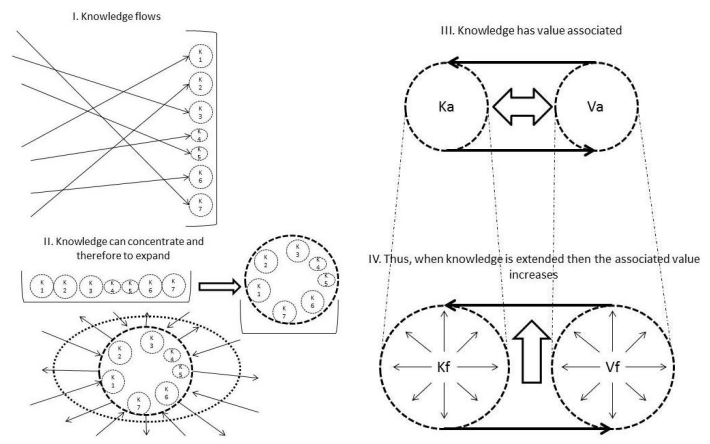

Figure 4: Relationship between knowledge and value within Inovcluster context - Source: Inovcluster - adapted from Santos et al. (2011) - INAGRI -Rede de Oficinas de Inovação pra o sector Agroindustrial

As previously stated Inovcluster is organized into intervention in different areas and it is within the Trends and Innovation Unit and the projects development area, with the science partners, that the knowledge transfer occurs. As the next figures illustrate (see figure 5 and 6 ), the Trends and Innovation Unit seeks to develop several activities, centred on user-driven innovation, studying consumers, so that it is possible to systematize information about the main market trends, consumer behaviour and client profile for all the subsectors operating in the cluster. The scientific and applied projects have a broader scope by promoting and developing scientific and technologic solutions for all agro-industrial sectors.

Through the years, Inovcluster has promoted more than 100 meetings, seminars, workshops or knowledge transfer events, with the purpose of transmitting market information, sharing market experiences and helping companies, in an innovation management perspective, to incorporate and develop their new products, processes or services, as we may see in figure 7 . 


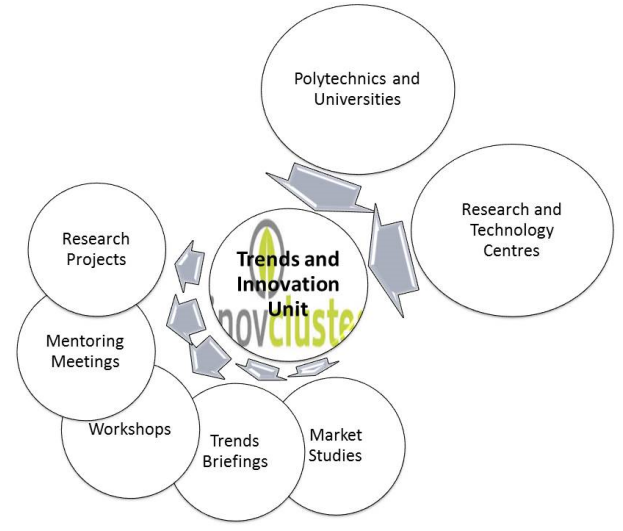

Figure 5: User-Driven Innovation Activities

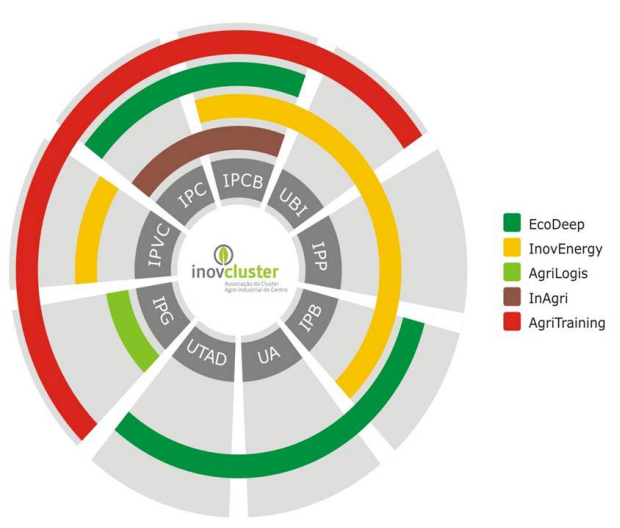

Figure 6: RDT - Research, Development and Technology cooperation projects

There are some relevant cases to demonstrate the importance of the experience and mentoring role of the Inovcluster performance in the business activity of its associates.

\section{Case Study}

The first case study presented here is the "Wine consumer study", developed with an important Portuguese wine company, illustrated in figure 8. After participating in a seminar about competitiveness and innovation, Global Wines, a wine business group with several brands within different Portuguese wine regions, (in particularly

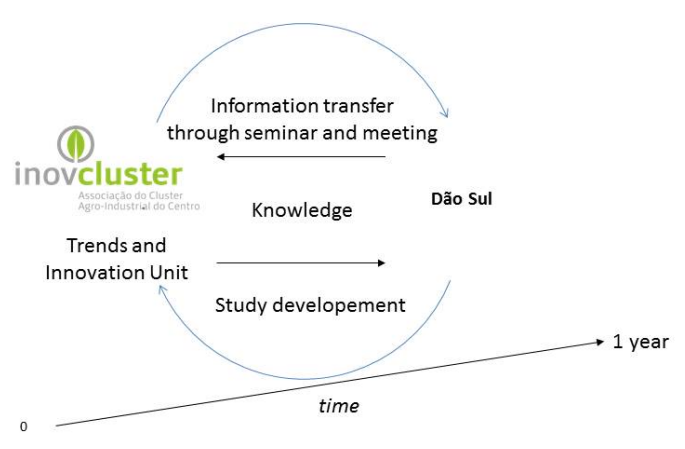

Figure 7: Mechanism for creating added value Dão Sul case study

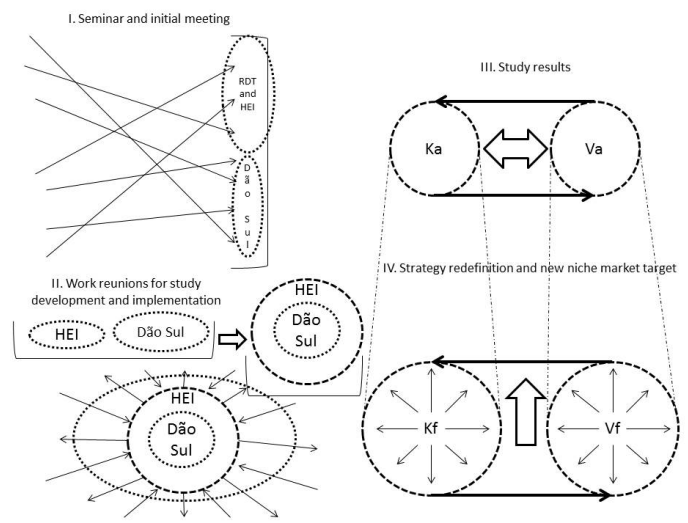

Figure 8: Relationship between knowledge and value: Inovcluster/ Higher Education Institution (HEI) partner and Dão Sul

their company Dão Sul, located in the Centre Region and a cluster associate) contacted us to propose the development of a national consumer study with the objective of understanding wine consumption behaviour and purchase in the supermarkets. This project was to be developed in one year.

After several meetings and sharing of information, the study was designed and implemented.

This study enabled them to redefine their commercial strategy and to identify a market niche composed of young male consumers who wanted a more "light" sparkling wine with which to celebrate and party. This niche wasn't occupied yet

IJFS | April 2016 | Volume 5 | pages 54-60 


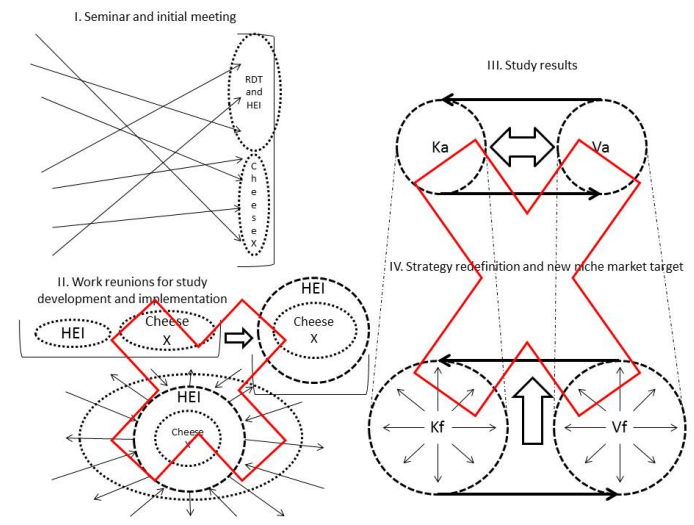

Figure 9: Relationship between knowledge and value: Inovcluster/ HEI+RDT and Cheese X

in the Portuguese market and Global Wines was able to develop the product which is nowadays a sales success.

Nevertheless, sometimes there is no immediate success on the knowledge transfer. For example a cheese manufacturer (we are not allowed to state its name), also after a seminar to let people know about the latest trends and innovation on the world market, elected to launch a new product for their current clients (innovation incorporation). Without talking with the Trends and Innovation Inovcluster Unit first, they invested in equipment and material to produce sliced cheese through the same market channels for the same target consumers (see figure 9).

Trends and innovation have to be adapted to the company's characteristics, as well as to their market, or else they imply a different market strategy. So the obvious result for this SME that worked with traditional clients and distribution channels was not very good: their consumers didn't accept the innovation, since their main concern and purchase decision criterion was price and the new product was inevitably more expensive than cheese sold by weight. The other problem noticed was in the packaging design and material since it caused deterioration of the cheese colour (not its flavour or organic characteristics but its colour). These two negative facts turned the product launch into a failure. This situation would have been avoided if Inovcluster had been a part of the innovation process and through its scientific and technical partners could have developed their innovation strategy, since it has the experience and knowledge, within their HEI and RDT partners to know that trends and innovation have to be carefully designed and implemented. Benchmarking is not a "copy paste" procedure. At the present time they have talked to the cluster to help them develop a new package and define a new commercial strategy.

\section{Discussion}

As previously stated, we may observe that the user-driven model created by Inovcluster works if meetings and discussions take place, so that knowledge transfer is clear and adapted to the business objectives of the companies, as seen in Lee (2009) .

When unaided, enterprises might not know how to implement innovation, in particular if they are SMEs with no research and innovation unit and no experience in innovation management.

We are aware that this model also works because of the proximity that Inovcluster has with its businesses and HEI / RDT associates, since it is easy to implement work meetings and also due to the sensibility of the research and innovation partners in accessing and communicating with the distinct companies.

It's a model of knowledge transfer adapted to the typology of associates and to a geographic region.

\section{References}

Bar, F. \& Riis, A. M. (2000). Tapping userdriven innovation: a new rationale for universal service. Information Society, 16(2), 99-108.

Chang, Y.-C. \& Chen, M.-H. (2004). Comparing approaches to systems of innovation: the knowledge perspective. Technology in Society, 26(1), 17-37.

Clusters and Support for SMEs Unit. (2012). Smart Guide to Service Inovation (2012). Book series. Ed. European Union. doi:10. $2769 / 51902$ 
COIN - Collaborative Innovation Networks. (2009). MIT (Sloan School of Management); SCAD (Savannah College of Art and Design); University of Cologne (Dept. of Information Systems and Inf. Mgmt.); Aalto University School of Science and Technology (formerly Helsinki University of Technology (SoberIT)). Retrieved from http : / / sites . google . com / site / coincourse2009/

Committee of the Regions of the European Union. (2012). Delivering on the Europe 2020 Strategy - Handbook for Local and Regional Authorities. European Union. doi: $10.2863 / 55820$

Doranova, A., Griniece, E., Miedzinsky, M., \& Reid, A. (2012). Connecting Smart and Sustainable Growth through Smart Specialisation - A practical guide for ERDF managing authorities. European Union. Retrieved from http: / / poalgarve21.ccdralg.pt/site/sites/poalgarve21.ccdr-alg.pt/ files / 2014-2020/3._connecting_smart_and_ sustainable_growth_guide_comp.pdf

Foray, D., Goddard, J., Goenaga, X., Landabaso, M., McCann, P., Morgan, K., ... Ortega Argiles, R. (2012). Guide to Research and Innovation Strategies for Smart Specialisations (RIS 3). Luxembourg: Publications Office of the European Union, 2012, European Commission. doi:10.2776/65746

Gomes, P. N. \& Francisco, A. F. (2013). Introdução aos estudos de tendências: conceitos e modelos. Estoril: Trends Research Center.

GTZ. (2007). Valuelinks manual - the methodology of value chain promotion. First Edition, Springer-Heinze, Andreas (ed.) Retrieved from http://www2.giz.de/wbf/ 4tDx9kw63gma/ValueLinks_Manual.pdf

Holmquist, L. E. (2004). User-driven innovation in the future applications lab. In $\mathrm{Chi}^{\prime} \mathrm{O}_{4} \mathrm{ex}$ tended abstracts on human factors in computing systems (pp. 1091-1092). ACM. Retrieved from http: / / citeseerx.ist.psu.edu/ viewdoc/download? doi $=10.1 .1 .90 .9518 \%$ 5 C\&rep $=$ rep $1 \% 5$ C\&type $=$ pdf

ILO. (2009). Guide for value chain analysis and upgrading. Retrieved from http://www . value- chains . org / dyn / bds / docs / detail / $545 / 6$

Lee, C.-Y. (2009). Do firms in clusters invest in R\&D more intensively? Theory and evidence from multi-country data. Research Policy, 38(7), 1159-1171. doi:10.1016/j . respol.2009.04.004

Organisation for Economic Cooperation and Development. (2013). Draft synthesis report on innovation driven growth in regions: the role of smart specialization. OECD's Working Party on Innovation and Technology Policy (TIP). Retrieved from https:// community.oecd.org/thread/14571

Pedroni, M. (2011). From fashion forecasting to coolhunting. Previsional models in fashion and in cultural production [Online]. Retrieved from http : / / www . inter disciplinary . net / wp - content / uploads / 2010/08/mpedronipaper.pdf

Rosted, J. (2005). User-driven innovation. Results and recommendations. Copenhagen: Fora. Retrieved from http : / / www . euc2c . com / graphics / en / pdfs / mod3 / userdriveninnovation.pdf

Santos, H. P., Andrade, L. P., Pereira, C. D., Rodrigues, A. M., Cerqueira, C., \& Ferreira, A. (2011). InAgri - Rede de Oficinas de Inovação para o sector Agro-Industrial. Inovcluster, Portugal. Retrieved from http: / / www . inagri.org / wp-content/ uploads / documentos / REDE- DE- OFICINAS-DEINOVA \%C3\%87\%C3\%830_8.6.pdf

Smart Specialization Platform. (2011). Connecting Universities to Regional Growth: A Practical Guide European. Retrieved from http : / / ec . europa. eu / regional_ policy / sources / docgener / presenta / universities2011/universities2011_en.pdf

UNIDO. (2011). Industrial Value Chain Diagnostics: An Integrated Tool. United Nations Industrial Development Organization (UNIDO). Vienna, Austria. Retrieved from http: / / www . value- chains . org / dyn / bds / docs/811/IVC_Diagnostic_Tool.pdf 